\title{
Anion Effects on Sodium Ion and Acid Molecule Adduction to Protein Ions in Electrospray Ionization Mass Spectrometry
}

\author{
Tawnya G. Flick, Samuel I. Merenbloom, Evan R. Williams \\ Department of Chemistry, University of California-Berkeley, Latimer Hall \#1460, Berkeley, CA 94720-1460, USA
}

\begin{abstract}
Gaseous protein-metal ion and protein-molecule complexes can be readily formed by electrospray ionization (ESI) from aqueous solutions containing proteins and millimolar concentrations of sodium salts of various anions. The extent of sodium and acid molecule adduction to multiply charged protein ions is inversely related and depends strongly on the proton affinity (PA) of the anion, with extensive sodium adduction occurring for anions with PA values greater than $\sim 300 \mathrm{kcal} \cdot \mathrm{mol}^{-1}$ and extensive acid molecule adduction occurring for anions with PA values less than $315 \mathrm{kcal} \cdot \mathrm{mol}^{-1}$. The role of the anion on the extent of sodium and acid molecule adduction does not directly follow the Hofmeister series, suggesting that direct proteinion interactions may not play a significant role in the observed effect of anions on protein structure in solution. These results indicate that salts with anions that have low PA values may be useful solution-phase additives to minimize nonspecific metal ion adduction in ESI experiments designed to identify specific protein-metal ion interactions.
\end{abstract}

Key words: Anion, Sodium, Adduction, Electrospray, Hofmeister series, Proteins

\section{Introduction}

Ton-protein interactions are ubiquitous in nature where they 1 play a role in many biological functions. Some membrane proteins form channels in cell walls to selectively transport certain ions into and out of the cytoplasm [1-3]. Perhaps the best known examples are the sodium and potassium ion channels, which combine to create the action potentials necessary for the function of the nervous system $[1,2]$. Other channels specific to the transport of calcium and chloride ions contribute to the cardiac action potentials [2, 3]. Proteins with EF-hand motifs, such as calmodulin and troponin-C, bind calcium ions in order to regulate functions such as inflammation, metabolism, skeletal- and smoothmuscle contraction, and memory $[4,5]$. Protein-metal ion interactions have also been implicated in the misfolding and subsequent aggregation of proteins resulting in the formation of plaques and fibrils in both prion-based [6-8] and Alzheimer's diseases [9, 10]. Both metal chelators and

Correspondence to: Evan R. Williams; e-mail: williams@cchem.berkeley.edu redistribution of metals within the brain are actively pursued as potential treatments for Alzheimer's disease [9, 10].

In addition to specific ion-protein interactions, ions can also affect the stability, solubility, and function of proteins through nonspecific interactions. Nearly 125 years ago, Franz Hofmeister first published his findings on how different ions affect protein solubility, resulting in an ordering of ions based on their propensity to stabilize or destabilize protein structure [11, 12]:

$$
\begin{aligned}
\mathrm{F}^{-} \approx \mathrm{COOH}^{-} \approx & \mathrm{SO}_{4}^{2-}>\mathrm{Cl}^{-}>\mathrm{Br}^{-}>\mathrm{NO}_{2}{ }^{-}>\mathrm{I}^{-} \\
& >\mathrm{ClO}_{4}^{-}>\mathrm{SCN}^{-}
\end{aligned}
$$

Ions towards the left of this series (kosmotropes) stabilize proteins and cause them to precipitate, whereas ions to the right of the series (chaotropes) destabilize proteins and make them more soluble in aqueous solutions. Hofmeister effects correlate well with many ionic properties, including ionic radii [13, 14], polarizabilities [14], solvation free energies [13-15], viscosity coefficients [15], surface tension of 
aqueous solutions [16, 17], and elution times from SephadexG10 columns.[18] The effect of ions on protein stability is known to vary both with isoelectric point (pI) of the protein and $\mathrm{pH}$ of solution $[14,19,20]$, and anions generally have a larger effect than cations.

Despite numerous studies using many different methods, the origins of these phenomena are still widely debated. Evidence supporting both direct ion-protein interactions as well as ion-induced water ordering has been reported [1327], but the relative importance of these effects is not well understood. Results from time-resolved spectroscopy experiments indicate that sulfate, a strong kosmotrope, does not affect the reorientation time of water molecules beyond the first solvation shell [26], which has been interpreted as evidence that ion-induced water ordering does not play a significant role in the Hofmeister effect. However, recent infrared photodissociation studies of gaseous hydrated sulfate indicate that this anion can pattern the structure of water well past the second solvation shell [25]. Additional recent evidence suggests that many different ions can affect the structure of water past the first and even second solvent shell to various extents [27].

Ion adduction to proteins often occurs with both electrospray ionization (ESI) [28-37] and matrix assisted laser desorption/ionization (MALDI) [37-40]. Signal suppression in ESI can occur even when low concentrations of many salts are present [33-37, 41, 42], and extensive sodium adduction to both proteins and DNA frequently occurs [31-35, 42]. Salts are often removed by dialysis or using liquid chromatography to reduce adduction and improve ion formation in ESI [32, 36, 37]. Sodium adduction in ESI depends on the pI of the protein and the $\mathrm{pH}$ of the solution and more adduction typically occurs for low charge state ions [31, 34]. McLuckey and coworkers reported that sodium adduction to gaseous protein ions is the highest when the solution $\mathrm{pH}$ is several units or more greater than the $\mathrm{pI}$ of the protein, and can be significantly reduced when the solution $\mathrm{pH}$ is $\sim 3$ units lower than the $\mathrm{pI}$ in positive ion mode MS [31]. High concentrations of some additives, such as ammonium acetate, can reduce sodium adduction to proteins [34] and can be used to improve the mass measuring accuracy of large protein complexes where adducts to molecular ions are not resolved [35]. Konermann and coworkers found the extent of nonspecific calcium adduction to proteins was reduced when calcium tartrate was added to ESI solutions compared with calcium acetate and calcium chloride, and suggested that tartrate acts as a solution-phase chelator of calcium [28]. Gas-phase ion/ion reactions between DNA anions and several chelating ions, such as citrate, have also been shown to significantly reduce nonspecific metal ion adduction [42].

Anion and acid molecule adduction to biological molecules has also been observed in both ESI and in MALDI MS $[29,30,38-40,43,44]$. Gas-phase reactions of protein cations with anions can result in acid molecule adduction for anions with proton affinities $\sim 330 \mathrm{kcal} / \mathrm{mol}$ or lower [45, 46], and for reactions between protein ions and gaseous HI, the maximum number of $\mathrm{HI}$ adducts equals the number of basic sites less the number of protons [46]. Addition of $10 \mathrm{mM}$ perchloric acid to ESI solutions containing peptides or proteins leads to extensive adduction of acid molecules and can be used to accurately determine the number of basic sites in the molecule [29]. A similar relationship between the number of basic sites and the maximum extent of adduction has been observed for some acids in MALDI.[38-40] The presence of anions in ESI solutions containing neutral oligosaccharides, which do not have a highly acidic group, can increase the absolute intensity of the deprotonated molecular ions. A significant increase in the abundance of $(\mathrm{M}-\mathrm{H})^{-}$was observed for anions that have a higher proton affinity than that of the sugar, which was attributed to proton transfer from the oligosaccharide to the anion being favored, whereas acid molecule adduction was observed when the proton affinity of the anion was less than that of the oligosaccharide [43].

Despite the common occurrence of ion and molecule adduction in ESI and MALDI, there are no direct studies of the Hofmeister effect on anion-protein interactions using MS. Colussi and co-workers measured ESI mass spectra of solutions containing mixtures of equimolar amounts of the sodium salts of monovalent anions and found that the relative intensities of the anions correlated well with both the ionic radii and the solvation free energies, two properties that have previously been related to the Hofmeister series [13]. Here, the effects of anions on adduction of ions and molecules to proteins was investigated by adding millimolar concentrations of sodium salts of various anions to aqueous solutions from which protein ions are formed using ESI. Significant differences in the extents of both sodium and acid molecule adduction to the protein ions are observed. These differences do not correlate well with solution-phase properties but do correlate well with the proton affinity of the anion. These results suggest that direct ion-protein interactions may not play a significant role in the origin of the Hofmeister series.

\section{Experimental}

ESI mass spectra were acquired using a LTQ-Orbitrap hybrid mass spectrometer (Thermo Electron, Bremen, Germany). Bovine ubiquitin, porcine insulin chain B, chicken egg white lysozyme, and equine cytochrome $c$ were from Sigma Aldrich (St. Louis, MO, USA) and dialyzed against 18.2 M $\Omega$ water (Milli-Q, Millipore, Billerica, MA, USA) using Slide-A-Lyzer cartridges (Thermo Scientific) with a molecular weight cut-off of $3500 \mathrm{Da}$ (insulin chain B, ubiquitin) or 10,000 Da (lysozyme, cytochrome c). The sodium salts of $\mathrm{F}^{-}(\geq 99 \%), \mathrm{COOH}^{-}(\geq 99 \%), \mathrm{NO}_{2}^{-}(\geq 97 \%)$, $\mathrm{Cl}^{-}$( $\left.\geq 99.5 \%\right), \mathrm{SCN}^{-}(\geq 98 \%), \mathrm{Br}^{-}(\geq 99 \%), \mathrm{I}^{-}(\geq 99.5 \%)$, $\mathrm{SO}_{4}{ }^{2-}(\geq 99 \%), \mathrm{ClO}_{4}^{-}(\geq 98 \%), \mathrm{PF}_{6}^{-}(\geq 98 \%)$, and $\mathrm{SbF}_{6}{ }^{-}$ 
(technical grade) were from Sigma Aldrich and were used without further purification. Solutions containing $10 \mu \mathrm{M}$ protein and $1.0 \mathrm{mM}$ of the salt were prepared by diluting aliquots of stock solutions in $18.2 \mathrm{M} \Omega$ water. The source region was heated to $\sim 210{ }^{\circ} \mathrm{C}$ in order to generate consistent signal, resulting in an electrospray emitter temperature of $\sim 180{ }^{\circ} \mathrm{C}$. An autosampler delivered $15.0 \mu \mathrm{L}$ injections of sample into the mass spectrometer at a flow rate of 50 $\mu \mathrm{L} \cdot \mathrm{min}^{-1}$ for a total analysis time of $7 \mathrm{~min}$, including a wash step after each sample. The high flow rate was used to decrease the total sample analysis time.

\section{Results and Discussion}

\section{Sodium and Acid Molecule Adduction}

ESI mass spectra of proteins acquired from aqueous solutions with millimolar concentrations of sodium salts of $\mathrm{F}^{-}, \mathrm{COOH}^{-}, \mathrm{NO}_{2}^{-}, \mathrm{Cl}^{-}, \mathrm{SCN}^{-}, \mathrm{Br}^{-}, \mathrm{I}^{-}, \mathrm{SO}_{4}{ }^{2-}, \mathrm{ClO}_{4}^{-}, \mathrm{PF}_{6}^{-}$, and $\mathrm{SbF}_{6}{ }^{-}$show various extents of sodium and acid molecule adduction depending on the counterion of the sodium salt and to a lesser extent, the identity of the protein. For example, ESI mass spectra of aqueous solutions containing $10 \mu \mathrm{M}$ ubiquitin and either $1.0 \mathrm{mM} \mathrm{NaF}$ or $\mathrm{NaSbF}_{6}$ are shown in Figure 1a and b, respectively. With $\mathrm{NaF}$, adduction of multiple sodium ions to the protein

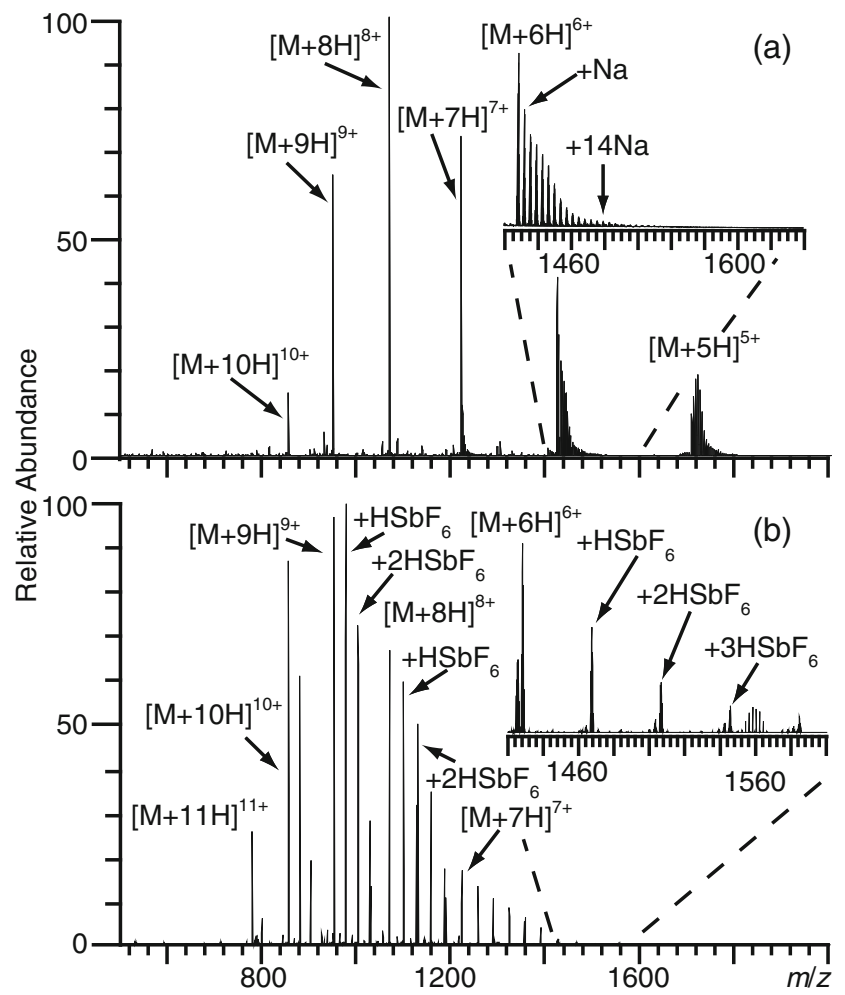

Figure 1. ESI mass spectra of aqueous solutions containing $10 \mu \mathrm{M}$ ubiquitin and $1.0 \mathrm{mM}$ (a) $\mathrm{NaF}$ or (b) $\mathrm{NaSbF}_{6}$. Insets show various extents of sodium and acid molecule adduction to the $6+$ charge state occurs, with a significantly greater extent of adduction observed for lower charge state ions, as has been reported previously $[31,34]$. For the $6+$ charge state, the abundance of the single sodium adduct is $\sim 70 \%$ that of the protonated molecular ion, and adduction of up to 23 sodium ions, ( $\mathrm{M}$ $17 \mathrm{H}+23 \mathrm{Na})^{6+}$, is observed. No $\mathrm{HF}$ adducts to any charge state are detected. In striking contrast, no additional sodium adduction occurs with $1.0 \mathrm{mM} \mathrm{NaSbF}_{6}$ compared with that obtained when the protein is sprayed from an aqueous solution without salt added. However, extensive adduction of $\mathrm{HSbF}_{6}$ occurs (Figure 1b). Acid molecule adduction to the $6+$ and $11+$ charge states accounts for approximately $61 \%$ and $13 \%$, respectively, of the total ion abundance of each charge state, consistent with the greater extent of acid molecule adduction for lower charge state ions observed previously [30, 45].

A wide range of charge states were produced from these aqueous solutions owing to the high source temperature used. Proteins can denature at high temperatures, which results in a broader distribution of charge states centered at higher charge [47]. Because sodium ion and acid molecule adduction were most prevalent for lower charge states, a low charge state ion that was common to each protein for all salts examined was chosen to compare the various extents of adduction. For example, partial mass spectra showing the $6+$ charge state of ubiquitin obtained from solutions containing (a) no added salt or $1.0 \mathrm{mM}$ of (b) $\mathrm{NaCl}$, (c) $\mathrm{Na}_{2} \mathrm{SO}_{4}$, (d) $\mathrm{NaClO}_{4}$, or (e) $\mathrm{NaPF}_{6}$ are shown in Figure 2. The percent adduction of sodium to the protonated molecular ion relative to that from an aqueous solution without salt added is $77 \%$, $60 \%, 37 \%$, and $0 \%$ for these respective salts. There is no adduction of $\mathrm{HCl}$, but $\mathrm{H}_{2} \mathrm{SO}_{4}, \mathrm{HClO}_{4}$, and $\mathrm{HPF}_{6}$ adducts at $21 \%, 40 \%$, and $58 \%$ of the total ion intensity for the $6+$ charge state, respectively, are formed. Sodium adducts with one or more acid molecules attached are included in the total percent acid adduction reported. Although equimolar concentrations of sodium are added to the ESI solutions in the form of various salts, except for $\mathrm{Na}_{2} \mathrm{SO}_{4}$, the extent of both sodium and acid molecule adduction to ubiquitin $6+$ is significantly different.

ESI mass spectra of aqueous solutions containing $10 \mu \mathrm{M}$ lysozyme with $1.0 \mathrm{mM}$ of the sodium salt of $\mathrm{F}^{-}, \mathrm{COOH}^{-}$, $\mathrm{NO}_{2}^{-}, \mathrm{Cl}^{-}, \mathrm{SCN}^{-}, \mathrm{Br}^{-}, \mathrm{I}^{-}, \mathrm{SO}_{4}{ }^{2-}, \mathrm{ClO}_{4}^{-}, \mathrm{PF}_{6}^{-}$, or $\mathrm{SbF}_{6}^{-}$were obtained under identical conditions. Lysozyme $(\mathrm{pI}=11)$ has a significantly higher isoelectric point than ubiquitin ( $\mathrm{pI}=$ 6.6). Figure 3 shows the $9+$ charge state of lysozyme formed by ESI from aqueous solutions containing $10 \mu \mathrm{M}$ protein with (a) no added salt or $1.0 \mathrm{mM}$ of (b) $\mathrm{NaF}$, (c) $\mathrm{NaCl}$, (d) $\mathrm{Na}_{2} \mathrm{SO}_{4}$, (e) $\mathrm{NaClO}_{4}$, or (f) $\mathrm{NaPF}_{6}$. Sodium adduction to the protonated molecular ion is the greatest with $\mathrm{NaF}$ and $\mathrm{NaCl}$ with $41 \%$ and $31 \%$ adduction to the protonated molecular ion, respectively, whereas there is no adduction of $\mathrm{HF}$ or $\mathrm{HCl}$. There is $24 \%$ less sodium adduction with $\mathrm{Na}_{2} \mathrm{SO}_{4}$ compared with $\mathrm{NaCl}$, similar to the results for ubiquitin $6+$. Minimal sodium adduction occurs with $\mathrm{NaClO}_{4}$ and $\mathrm{NaPF}_{6}$ ( $<2 \%$ and $<1 \%$, respectively). Adducts of $\mathrm{H}_{2} \mathrm{SO}_{4}, \mathrm{HClO}_{4}$, 
Figure 2. Partial ESI mass spectra showing the 6+ charge state of ubiquitin obtained from aqueous solutions containing $10 \mu \mathrm{M}$ ubiquitin and (a) no added salt, and $1.0 \mathrm{mM}$ of the following salts: (b) $\mathrm{NaCl}$, (c) $\mathrm{Na}_{2} \mathrm{SO}_{4}$, (d) $\mathrm{NaClO}_{4}$, or (e) $\mathrm{NaPF}_{6}$

and $\mathrm{HPF}_{6}$ are observed, and account for approximately $77 \%$, $87 \%$, and $81 \%$ of the total ion intensity for the $9+$ charge state.

Various extents of acid molecule and sodium adduction to either lysozyme $9+$ or ubiquitin $6+$ were observed from the addition of different sodium salts to ESI solutions containing either of these proteins. The percent sodium and acid molecule adduction were determined for the eleven sodium salts for ubiquitin $6+(\mathrm{pI}=6.6)$, lysozyme $9+(\mathrm{pI}=$ $11)$, insulin chain B $2+(\mathrm{pI}=6.9)$, and cytochrome $c 9+(\mathrm{pI}=$ 10). Based on observations for all proteins, the general ordering of anions was:

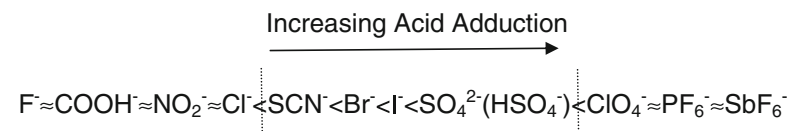

No Acid Adduction

High Acid Adduction

Sodium ion adduction was observed to be inversely related to the extent of acid molecule attachment; however, greater variation was observed at high levels of sodium ion adduction.

\section{Adduction and Solution-phase Properties}

The various extents of sodium and acid molecule adduction obtained when different anions are in these solutions were compared with common solution-phase properties. All the salts used here are soluble in water at $1.0 \mathrm{mM}$, but the salt concentration in the ESI droplet increases due to evaporation of water. Late in the droplet lifetime, the salts may reach their solubility limit and precipitate in the droplet, reducing the maximum number of potential adducts to the protein [34]. The percent sodium and acid molecule adduction to ubiquitin $6+$ as a function of the solubility product constant $\left(\mathrm{K}_{\mathrm{sp}}\right)$ of the sodium salt is shown in Figure $4 \mathrm{a}$. NaI and $\mathrm{NaNO}_{2}$ have similar $\mathrm{K}_{\mathrm{sp}}$ values, but addition of $\mathrm{NaNO}_{2}$ results in $22 \%$ greater sodium adduction than $\mathrm{NaI}$ even though the concentration of $\mathrm{Na}^{+}$in these solutions is the same. In contrast, the percent sodium adduction with $\mathrm{NaSCN}$ and $\mathrm{NaBr}$ differs by $<4 \%$ although their $\mathrm{K}_{\text {sp }}$ values differ by nearly three orders of magnitude. Extensive acid molecule adduction occurs for both $\mathrm{H}_{2} \mathrm{SO}_{4}(21 \%)$ and $\mathrm{HClO}_{4}(40 \%)$, but the $\mathrm{K}_{\text {sp }}$ values of the sodium salts are two orders of magnitude different.

Addition of ammonium acetate at high levels can result in a significant decrease in the extent of sodium adduction to protein ions [34, 35]. Although acetate can complex with sodium and precipitate out of solution at high
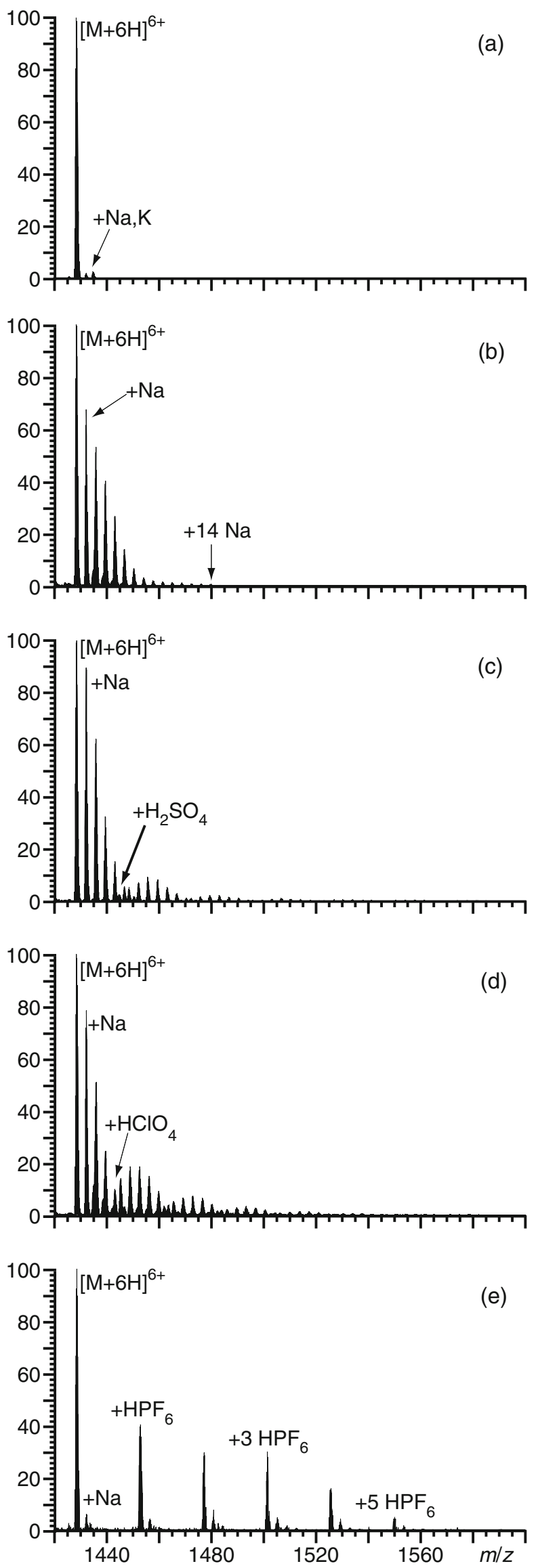
Figure 3. Partial ESI mass spectra showing the 9+ charge state of lysozyme obtained from aqueous solutions containing $10 \mu \mathrm{M}$ lysozyme and (a) no added salt, and $1.0 \mathrm{mM}$ of each of the following salts: (b) $\mathrm{NaF}$, (c) $\mathrm{NaCl}$, (d) $\mathrm{Na}_{2} \mathrm{SO}_{4}$, (e) $\mathrm{NaClO}_{4}$, or (f) $\mathrm{NaPF}_{6}$

concentrations, the percent sodium or acid molecule adduction to the protonated molecular ion does not correlate directly to the solubility of the sodium salt at the concentrations used here. Sodium adduction to ubiquitin $6+$ is highest with $\mathrm{NaF}$ and $\mathrm{NaCl}, 84 \%$ and $77 \%$, respectively, even though their solubilities differ by $\times 40$. These data indicate that the extent of sodium and acid molecule adduction does not correlate well with the solubility of these sodium salts.

The percent acid molecule and sodium adduction for ubiquitin $6+$ as a function of the $\mathrm{pK}_{\mathrm{a}}$ of the acid of the corresponding anion is shown in Figure 4b. A similar level of sodium adduction to ubiquitin $6+$ is observed with $\mathrm{NaF}$ and $\mathrm{NaCl}, 84 \%$ and $77 \%$, respectively, even though $\mathrm{HF}$ is a weak acid $\left(\mathrm{pK}_{\mathrm{a}}=3.2\right)$ and $\mathrm{HCl}$ is a strong acid $\left(\mathrm{pK}_{\mathrm{a}}=-8.0\right)$. $\mathrm{HI}$ and $\mathrm{HClO}_{4}$ are both strong acids, with $\mathrm{pK}_{\mathrm{a}}$ values of -11 and -10 , respectively; however, the corresponding acid molecule adduction observed for these two anions are 3\% and $40 \%$, respectively. These data indicate the extent of acid molecule and sodium adduction does not correlate well with the $\mathrm{pK}_{\mathrm{a}}$ of the protonated anion.

\section{Adduction and Proton Affinity}

The extent of acid molecule and sodium adduction were compared with the proton affinity (PA) of the anion $\left(\mathrm{A}^{-}\right)$. $\mathrm{PA}$ of $\mathrm{A}^{-}$is the negative enthalpy change for the gas-phase reaction:

$$
\mathrm{A}^{-}+\mathrm{H}^{+} \longrightarrow \mathrm{AH} \quad \mathrm{PA}\left(\mathrm{A}^{-}\right)=-\Delta \mathrm{H}_{\mathrm{rxn}}
$$

Results for ubiquitin $6+$ and insulin chain $\mathrm{B} 2+$ are shown in Figure 5a and b, respectively. $\mathrm{SbF}_{6}{ }^{-}$and $\mathrm{HPF}_{6}{ }^{-}$ have the two lowest PAs of the anions studied here, and the highest levels of acid molecule attachment and the lowest levels of sodium adduction to the protonated molecular ions $(<2 \%$ additional sodium adduction compared with that observed without salt addition) occurs for both the sodium salts of $\mathrm{SbF}_{6}{ }^{-}$and $\mathrm{PF}_{6}{ }^{-}$. NaF, which has the highest PA of the anions investigated, results in extensive sodium adduction, accounting for $84 \%$ and $39 \%$ of the total ion intensity for the $6+$ and $2+$ charge states of ubiquitin and insulin chain B, respectively. No HF adduction occurs with either protein. The extent of sodium ion and acid molecule adduction are inversely related, and are a strong function of the PA of the anion. The extent of sodium adduction increases and acid molecule adduction decreases as the PA of the anion increases across the range of $\sim 280-360 \mathrm{kcal} \cdot \mathrm{mol}^{-1}$. No or
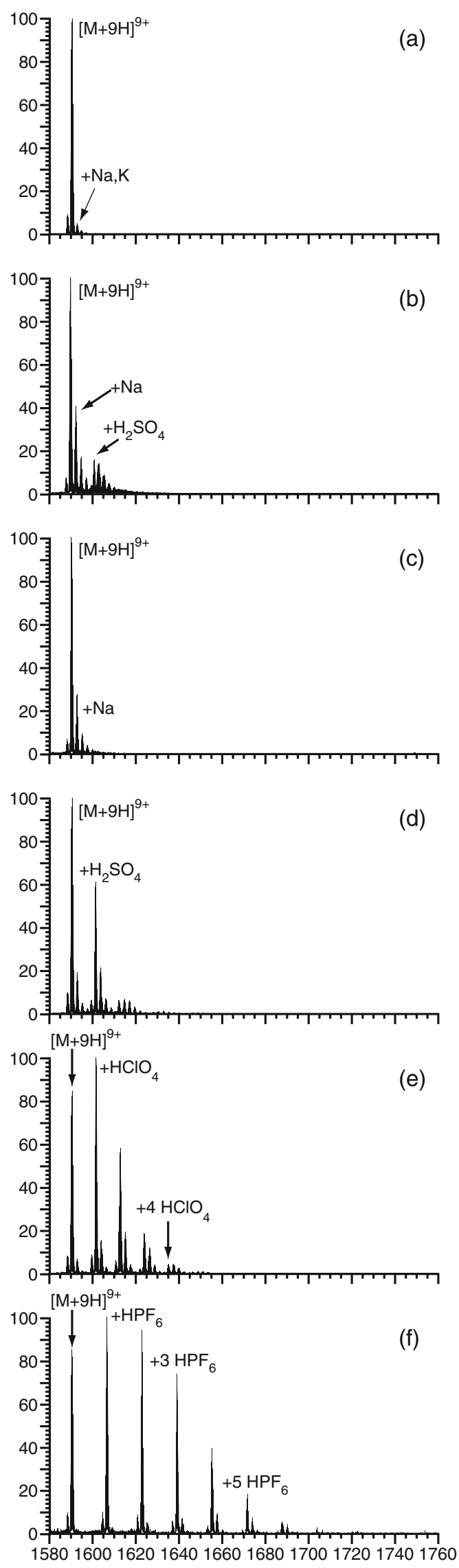

$\mathrm{m} / \mathrm{z}$ 


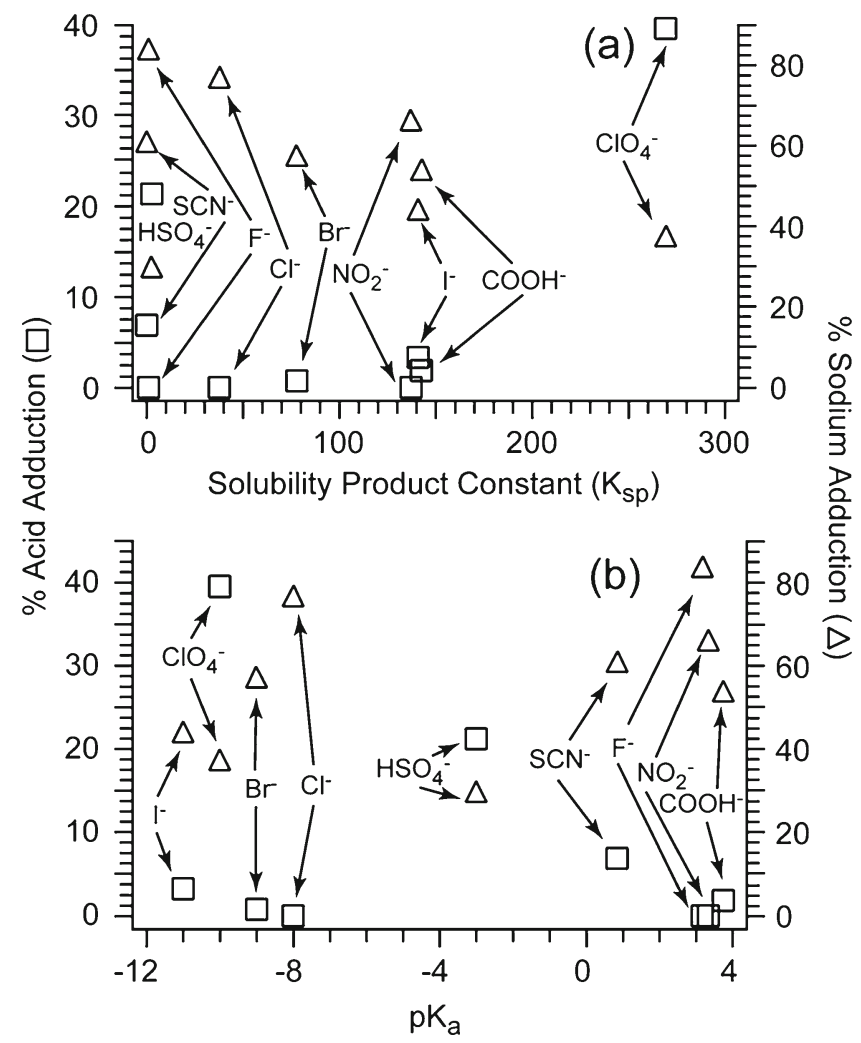

Figure 4. Percent acid molecule (squares) and sodium adduction (triangles) to ubiquitin $6+$ as a function of (a) $\mathrm{K}_{\mathrm{sp}}$ of the respective sodium salts or (b) $\mathrm{pK}_{\mathrm{a}}$ of the acid of the corresponding anion obtained from $10 \mu \mathrm{M}$ of ubiquitin with $1.0 \mathrm{mM}$ of $\mathrm{NaF}, \mathrm{NaCl}, \mathrm{NaCOOH}, \mathrm{NaNO}_{2}, \mathrm{NaBr}, \mathrm{NaSCN}, \mathrm{Nal}$, $\mathrm{Na}_{2} \mathrm{SO}_{4}$, or $\mathrm{NaClO}_{4}$ minimal acid molecule adduction occurs for anions with a PA greater than that of $\mathrm{NO}_{2}^{-}\left(330 \mathrm{kcal} \cdot \mathrm{mol}^{-1}\right)$. The transition between greater acid molecule adduction compared with sodium adduction occurs between 290$300 \mathrm{kcal} \cdot \mathrm{mol}^{-1}$ for both ubiquitin $6+$ and insulin chain B $2+$, corresponding to the sodium salts of $\mathrm{I}^{-}$and $\mathrm{ClO}_{4}{ }^{-}$. Acid molecule adduction increases from $3.2 \%$ to $40 \%$ and sodium adduction decreases from $44 \%$ to $37 \%$ with $\mathrm{NaI}$ and $\mathrm{NaClO}_{4}$, respectively, for ubiquitin $6+$. These data indicate that there is a significant change in the interaction between the anion and the protein that occurs for anions around the PA values where this transition between sodium ion and acid molecule adduction occurs.

Although $1.0 \mathrm{mM}$ solutions of $\mathrm{Na}_{2} \mathrm{SO}_{4}$ have twice the concentration of $\mathrm{Na}^{+}$as $1.0 \mathrm{mM}$ solutions of $\mathrm{NaF}$, sodium adduction to ubiquitin $6+$ is less for $\mathrm{Na}_{2} \mathrm{SO}_{4}$ $(60 \%)$ than for $\mathrm{NaF}(84 \%)$. Adduction of $\mathrm{H}_{2} \mathrm{SO}_{4}$ to ubiquitin $6+$ occurs, whereas no $\mathrm{HF}$ adduction is observed. The PA values of $\mathrm{SO}_{4}{ }^{2-}$ and $\mathrm{HSO}_{4}{ }^{-}$are 441 and $312 \mathrm{kcal} \cdot \mathrm{mol}^{-1}$, respectively. The extents of sodium and acid molecule adduction observed for $\mathrm{Na}_{2} \mathrm{SO}_{4}$ indicates that $\mathrm{HSO}_{4}^{-}$is most likely interacting with the protein. However, $\mathrm{SO}_{4}{ }^{2-}$ is most prevalent at $\mathrm{pH} \sim 7$. A $10^{3}$ - to $10^{4}$-fold increase in acidity from the neutral bulk solution can occur in the ESI droplets as evaporation occurs, resulting in a $\mathrm{pH}$ of approximately 2.6 to 3.3 [48]. The abundance of $\mathrm{HSO}_{4}^{-}$increases from $<0.001 \%$ to $\sim 17 \%$ of the total sulfate ions in solution as the $\mathrm{pH}$ decreases from 7 to 2.6, consistent with our conclusion
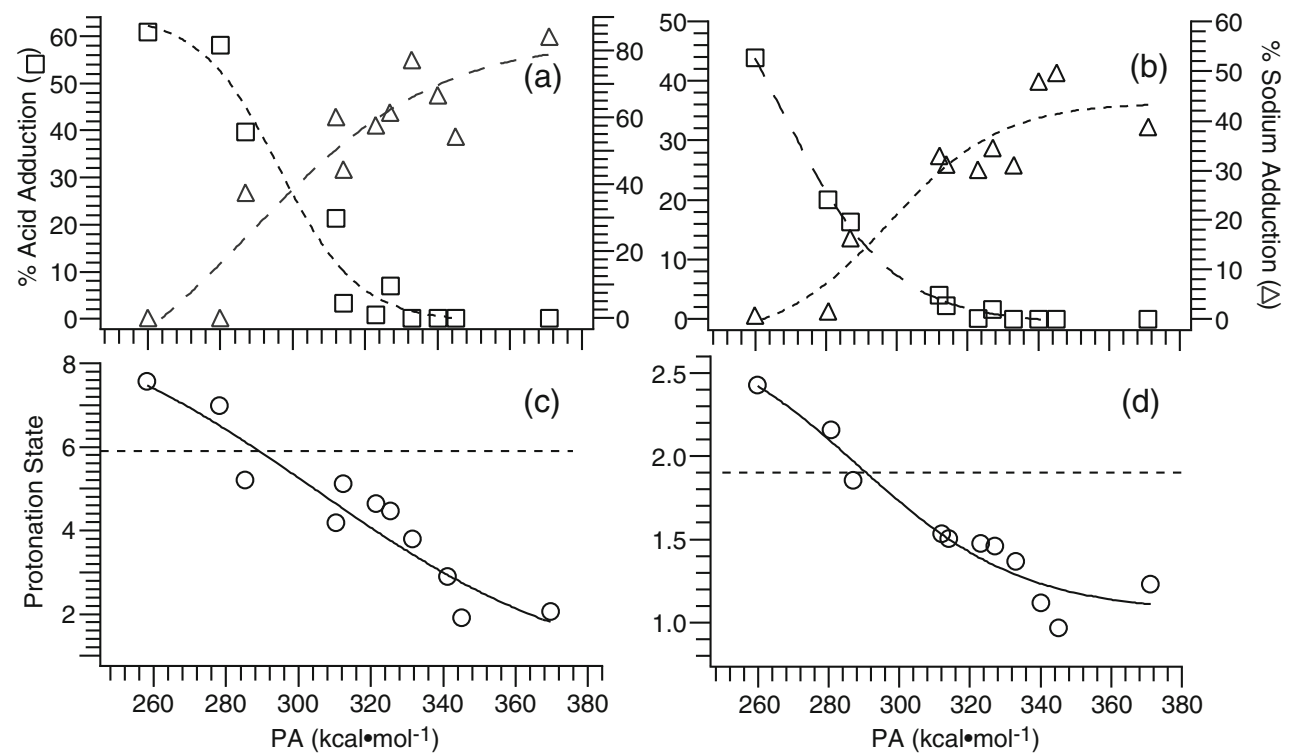

Figure 5. Percent acid molecule (squares) and sodium adduction (triangles) to (a) ubiquitin $6+$ or (b) insulin chain B $2+$ as a function of the proton affinity, PA $\left(\mathrm{kcal} \cdot \mathrm{mol}^{-1}\right)$, of the respective anion calculated from ESI mass spectra obtained from solutions containing $10 \mu \mathrm{M}$ protein with $1.0 \mathrm{mM}$ of NaF, $\mathrm{NaCl}, \mathrm{NaCOOH}, \mathrm{NaNO}_{2}, \mathrm{NaBr}, \mathrm{NaSCN}, \mathrm{Nal}, \mathrm{Na}_{2} \mathrm{SO}_{4}, \mathrm{NaClO}_{4}, \mathrm{NaPF}_{6}$, or $\mathrm{NaSbF}_{6}$. The extent of protonation of (c) ubiquitin 6+ and (d) insulin chain B 2+ as a function of the PA of the anion from the sodium salts. The dashed line corresponds to the extent of protonation of the protein from ESI solutions with no salt added 
that this is the form of the anion that interacts with the protein.

The extent of protonation for each charge state changes significantly depending on how much sodium or acid molecule adduction occurs, because each sodium adduct typically replaces a proton and each acid molecule adduct adds a proton. The extent of protonation for ubiquitin $6+$ and insulin chain B 2+, calculated as the average number of protons attached to these respective ions, as a function of the PA of the anion of the sodium salt are shown in Figure 5c and $\mathrm{d}$, respectively, and these data are compared with the extent of protonation from aqueous solutions with no salt added (dashed lines in Figure $5 \mathrm{c}$ and d). Greater protonation occurs for anions with PA values $<\sim 285 \mathrm{kcal} \cdot \mathrm{mol}^{-1}$, whereas less protonation occurs for anions with PA values $>287 \mathrm{kcal} \cdot \mathrm{mol}^{-1}$. One of the lowest extents of protonation observed for ubiquitin $6+$ and insulin chain B 2+ is 1.9 and 1.2 , respectively, with $\mathrm{NaF}$, the anion with the highest PA. These data indicate that the presence of the anion in the ESI solution directly affects the extent of protonation of the protein ions formed.

Similar results were obtained for lysozyme 9+ and cytochrome $c$ 9+ (Figure $6 \mathrm{a}$ and $\mathrm{b}$, respectively), two proteins with significantly higher isoelectric points than those of ubiquitin and insulin chain B. There is minimal sodium adduction and the greatest extent of acid molecule attachment to both proteins with $\mathrm{NaPF}_{6}$ and $\mathrm{NaSbF}_{6}$, the anions with the lowest PA values. Acid molecule adduction occurs for anions with a $\mathrm{PA}<323 \mathrm{kcal} \cdot \mathrm{mol}^{-1}$. The sodium salt of $\mathrm{F}^{-}$, which has the highest PA of the anions investigated, results in high levels of sodium adduction to the protonated molecular ion, $41 \%$ and $5.5 \%$ adduction to lysozyme $9+$ and cytochrome $c 9+$, respectively, and no HF adduction occurs. Results from the 11 sodium salts for all four proteins evaluated indicate that the extent of sodium adduction increases and acid molecule attachment decreases with increasing PA of the anion.

The extent of protonation for lysozyme 9+ and cytochrome $c 9+$ as a function of the PA of the anion of each sodium salt is shown in Figures $6 \mathrm{c}$ and d, respectively. For anions with PA values greater than $315 \mathrm{kcal} \cdot \mathrm{mol}^{-1}$, the extent of protonation is slightly lower than that with no salt added (dashed line), but this value is significantly higher when the PA of the anion is less than $\sim 315 \mathrm{kcal} \cdot \mathrm{mol}^{-1}$. The transition to higher extents of protonation occurs when acid molecule adduction on the protein is the most abundant and to lower extents of protonation when sodium adduction is most abundant and no acid molecule adduction occurs, indicating that these phenomena are related to the identity of the anion in the ESI solution.

The transition between sodium and acid molecule adduction is different for proteins with different isoelectric points. This transition occurs at PA values between 290 and $300 \mathrm{kcal} \cdot \mathrm{mol}^{-1}$ for both ubiquitin 6+ $(\mathrm{pI}=6.6)$ and insulin chain B 2+ $(\mathrm{pI}=6.9)$ and at $\sim 315 \mathrm{kcal} \cdot \mathrm{mol}^{-1}$ for lysozyme $9+(\mathrm{pI}=11)$ and cytochrome $c 9+(\mathrm{pI}=10)$. There is a sharper transition for lysozyme $9+$ and cytochrome $c 9+$, but the transition is similar for proteins with similar isoelectric points, indicating that the number of acidic and basic sites in a protein is a factor in the extent of adduction.
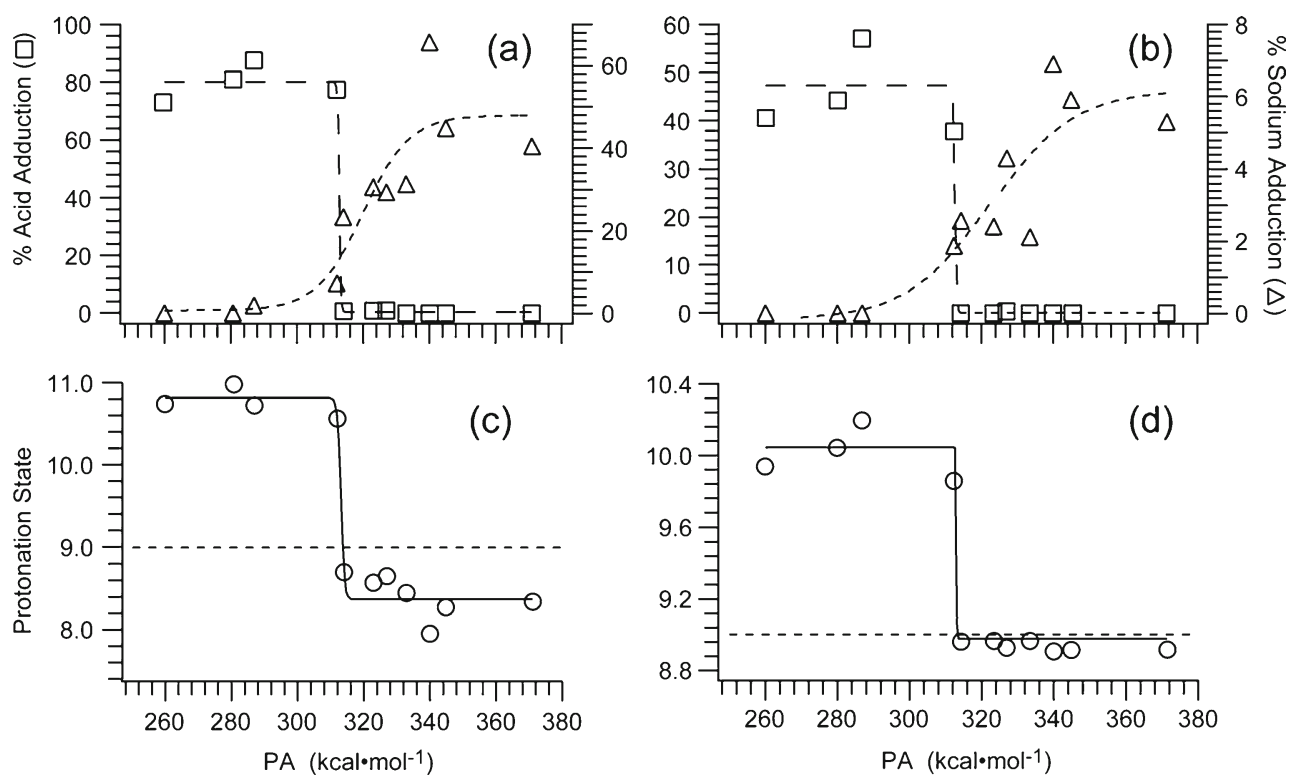

Figure 6. Percent acid molecule (squares) and sodium adduction (triangles) to (a) lysozyme 9+ and (b) cytochrome $c$ 9+ as a function of the proton affinity, $\mathrm{PA}\left(\mathrm{kcal} \cdot \mathrm{mol}^{-1}\right)$, of the anion calculated from ESI mass spectra of solutions containing $10 \mu \mathrm{M}$ protein with $1.0 \mathrm{mM}$ of $\mathrm{NaF}, \mathrm{NaCl}, \mathrm{NaCOOH}, \mathrm{NaNO}_{2}, \mathrm{NaBr}, \mathrm{NaSCN}, \mathrm{Nal}, \mathrm{Na}_{2} \mathrm{SO}_{4}, \mathrm{NaClO}_{4}, \mathrm{NaPF}_{6}$, or $\mathrm{NaSbF}_{6}$. The extent of protonation of (c) lysozyme 9+ and (d) cytochrome $c$ 9+ as a function of the PA of the anion from the sodium salts. The dashed line corresponds to the extent of protonation of the protein from ESI solutions with no salt added 


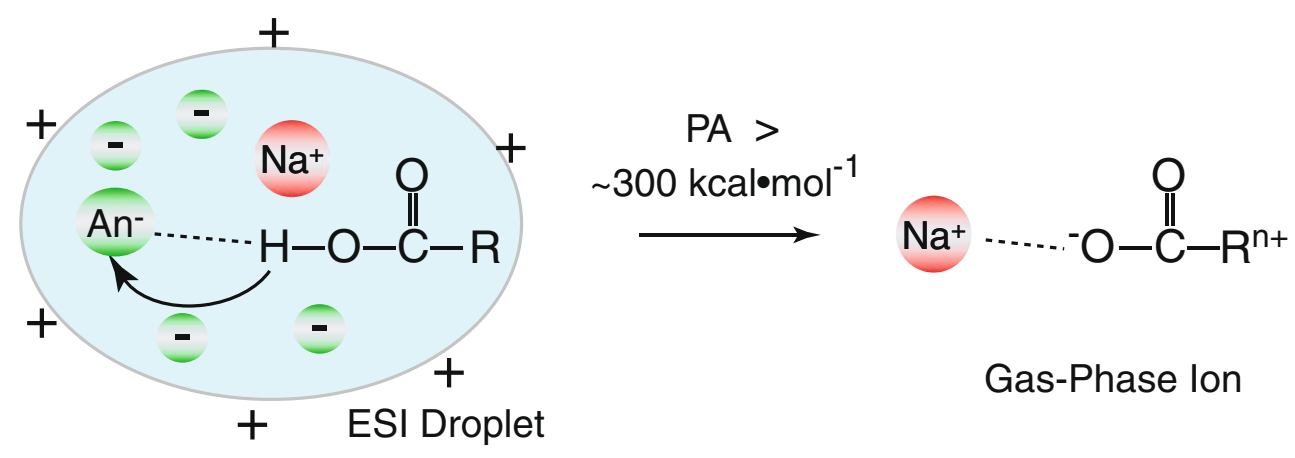

Scheme 1

\section{Adduction Mechanism}

There is an inverse correspondence between sodium and acid molecule adduction to these four proteins, which is a function of the PA of the anion. An anion can favorably interact with either basic or acidic sites in the protein via ionic interactions. For anions with a high PA $\left(>\sim 300 \mathrm{kcal} \cdot \mathrm{mol}^{-1}\right)$, deprotonation of the acidic sites in the protein (Glu, Asp, and the C-terminus) by the anion can be favorable (Scheme 1). The PA of acetate is $348 \mathrm{kcal} \cdot \mathrm{mol}^{-1}$, and this value provides a rough estimate of the intrinsic PA of a carboxylate group in a protein, although the values of the latter depend on many additional factors, including interand intramolecular solvation and proximity of other charged residues. Deprotonation of acidic sites in the protein by the anion in the late stages of droplet evaporation makes possible strongly favorable interactions between the deprotonated site and sodium cations, consistent with the extensive sodium adduction to proteins observed for anions with high PA values.

Differences in the extent of calcium adduction to protein ions formed by ESI from solutions containing different calcium salts have been reported [28]. The extent of nonspecific calcium adduction to $\alpha$-lactalbumin, $\beta$-lactoglobulin, calmodulin, and myoglobin was the greatest for calcium chloride and calcium acetate, and smallest for calcium tartrate [28]. These results were attributed to the ability of tartrate to sequester divalent metal cations during the final stages of the ESI droplet lifetime [28]. The PAs of chloride and acetate are 333 and $349 \mathrm{kcal} \cdot \mathrm{mol}^{-1}$, respectively, and nonspecific cation adduction would be predicted to be extensive from salts of these anions based on the trends observed here. The PA of the tartrate ion has not been reported, but adduction of tartrate to ubiquitin does occur (data not shown), indicating that the PA of this anion is lower than chloride and acetate. These results are consistent with the extent of nonspecific calcium adduction being a result of the PA of the anion as opposed to more specific complexation with the metal ion.

Anions with lower PA values can form ionic interactions with basic sites (Scheme 2) and adduction of anions to basic sites in peptides and proteins has been observed in both MALDI and ESI [29, 38-40]. Addition of small amounts of perchloric acid to ESI solutions containing peptides and proteins results in adduction of $\mathrm{HClO}_{4}$, and the maximum extent of adduction can be used to accurately determine the number of basic sites in these molecules [29]. Gaseous adduction of HI and other acids with $\mathrm{PA} \leq \sim 330 \mathrm{kcal} \cdot \mathrm{mol}^{-1}$ to proteins also occurs and can be related to the number of basic sites [45, 46]. Dissociation of the adducted complex results in loss of the neutral acid, consistent with the much higher PA of the anion compared with the basic site [29, 46]. The stabilities of these adducts increases with decreasing charge state [29], so more adduction is typically observed for lower charge state ions.
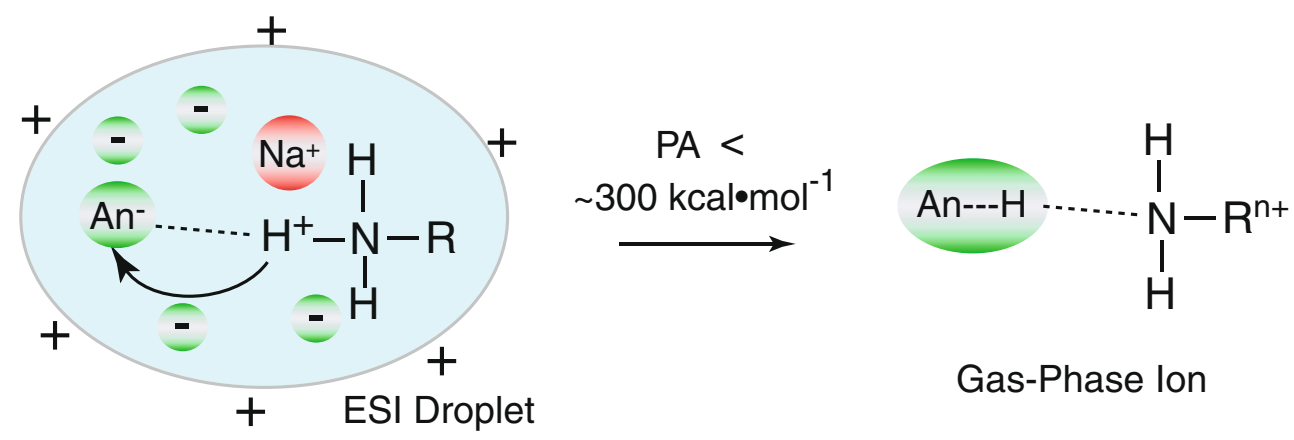

Scheme 2

\section{Gas-Phase Ion}




\section{Conclusions}

Addition of anions at millimolar concentration as the sodium salt to ESI solutions containing proteins results in different extents of acid molecule and sodium ion adduction to the protein ions. The extents of acid molecule and sodium ion adduction are inversely related, and depend primarily on the gas-phase PA of the anion and do not correlate well with solution-phase properties. Although there is some similarity in anion ordering, the effect of the anion on acid molecule and sodium adduction to the protein is not directly correlated to the Hofmeister series, suggesting that ion-protein interactions may not contribute as much as ion-water interactions to the Hofmeister effect. Although this study is limited to sodium salts, this work can be extended to salts for other cations. Proteins with low affinity for metal ions often require millimolar metal concentrations to induce significant binding in solution. For example, $\beta$-lactoglobulin has a low affinity calcium binding site with a dissociation constant around $3 \mathrm{mM}$ [49]. The use of salts with anions that have a relatively high $\mathrm{PA}$, such as chloride and acetate salts, may result in substantial nonspecific adduction to these proteins in ESI experiments, making it difficult to detect a specific metal-protein interaction. Salts with low PA anions should suppress nonspecific metal adduction to proteins and may be useful additives to ESI solutions in experiments aimed at measuring such low affinity-specific metal ion binding sites.

\section{Acknowledgments}

The authors acknowledge financial support from the National Science Foundation (grant CHE-1012833) and National Institutes of Health (grant 5F32GM093593-02 for fellowship support for S.I.M.).

\section{References}

1. MacKinnon, R.: Potassium Channels and the Atomic Basis of Selective Ion Conduction (Nobel Lecture). Angew. Chem. Int. Edit. 43, 42654277 (2004)

2. Catterall, W.A.: Structure and Function of Voltage-Gated Ion Channels. Annu. Rev. Biochem. 64, 493-531 (1995)

3. Hiraoka, M., Kawano, S., Hirano, Y., Furukawa, T.: Role of Cardiac Chloride Currents in Changes in Action Potential Characteristics and Arrhythmias. Cardiovasc. Res. 40, 23-33 (1998)

4. Crivici, A., Ikura, M.: Molecular and Structural Basis of Target Recognition by Calmodulin. Annu. Rev. Biophys. Biomol. Struct. 24, 85-116 (1995)

5. Ogawa, Y.: Calcium Binding to Troponin $\mathrm{C}$ and Troponin-Effects of $\mathrm{Mg}^{2+}$, Ionic-Strength, and pH. J. Biochem. 97, 1011-1023 (1985)

6. Jackson, G.S., Murray, I., Hosszu, L.L.P., Gibbs, N., Waltho, J.P., Clarke, A.R., Collinge, J.: Location and Properties of Metal-Binding Sites on the Human Prion Protein. Proc. Natl. Acad. Sci. U.S.A. 98, 8531-8535 (2001)

7. Lehmann, S.: Metal Ions and Prion Diseases. Curr. Opin. Chem. Biol. 6, 187-192 (2002)

8. Wong, B.S., Chen, S.G., Colucci, M., Xie, Z.L., Pan, T., Liu, T., Li, R. L., Gambetti, P., Sy, M.S., Brown, D.R.: Aberrant Metal Binding by Prion Protein in Human Prion Disease. J. Neurochem. 78, 1400-1408 (2001)

9. Duce, J.A., Bush, A.I.: Biological Metals and Alzheimer's Disease: Implications for Therapeutics and Diagnostics. Prog. Neurobiol. 92, 118 (2010)
10. Bush, A.I.: The Metallobiology of Alzheimer's Disease. Trends Neurosci. 26, 207-214 (2003)

11. Hofmeister, F.: Arch. Exp. Pathol. Pharmakol. 24, 247-260 (1888)

12. Kunz, W., Henle, J., Ninham, B.W.: 'Zur Lehre Von Der Wirkung Der Salze' (About the Science of the Effect of Salts): Franz Hofmeister's Historical Papers. Curr. Opin. Colloid Interface Sci. 9, 19-37 (2004)

13. Cheng, J., Vecitis, C.D., Hoffmann, M.R., Colussi, A.J.: Experimental Anion Affinities for the Air/Water Interface. J. Phys. Chem. B 110, 25598-25602 (2006)

14. Zhang, Y.J., Cremer, P.S.: The Inverse and Direct Hofmeister Series for Lysozyme. Proc. Natl. Acad. Sci. U.S.A. 106, 15249-15253 (2009)

15. Hribar, B., Southall, N.T., Vlachy, V., Dill, K.A.: How Ions Affect the Structure of Water. J. Am. Chem. Soc. 124, 12302-12311 (2002)

16. Cho, Y.H., Zhang, Y.J., Christensen, T., Sagle, L.B., Chilkoti, A., Cremer, P.S.: Effects of Hofmeister Anions on the Phase Transition Temperature of Elastin-Like Polypeptides. J. Phys. Chem. B 112, 13765-13771 (2008)

17. Zhang, Y., Furyk, S., Sagle, L.B., Cho, Y., Bergbreiter, D.E., Cremer, P.S.: Effects of Hofmeister Anions on the LCST of PNIPAM as a Function of Molecular Weight. J. Phys. Chem. C 111, 8916-8924 (2007)

18. Washabaugh, M.W., Collins, K.D.: The Systematic Characterization by Aqueous Column Chromatography of Solutes which Affect Protein Stability. J. Biol. Chem. 261, 2477-2485 (1986)

19. Bostrom, M., Tavares, F.W., Finet, S., Skouri-Panet, F., Tardieu, A., Ninham, B.W.: Why Forces between Proteins Follow Different Hofmeister Series for $\mathrm{pH}$ above and Below pI. Biophys. Chem. 117, 217-224 (2005)

20. Finet, S., Skouri-Panet, F., Casselyn, M., Bonnete, F., Tardieu, A.: The Hofmeister Effect as Seen by SAXS in Protein Solutions. Curr. Opin. Colloid Interface Sci. 9, 112-116 (2004)

21. Uejio, J.S., Schwartz, C.P., Duffin, A.M., Drisdell, W.S., Cohen, R.C., Saykally, R.J.: Characterization of Selective Binding of Alkali Cations with Carboxylate by X-Ray Absorption Spectroscopy of Liquid Microjets. Proc. Natl. Acad. Sci. U.S.A. 105, 6809-6812 (2008)

22. Smith, J.D., Saykally, R.J., Geissler, P.L.: The Effects of Dissolved Halide Anions on Hydrogen Bonding in Liquid Water. J. Am. Chem. Soc. 129, 13847-13856 (2007)

23. Freire, M.G., Neves, C., Silva, A.M.S., Santos, L., Marrucho, I.M., Rebelo, L.P.N., Shah, J.K., Maginn, E.J., Coutinho, J.A.P.: H-1 NMR and Molecular Dynamics Evidence for an Unexpected Interaction on the Origin of Salting-In/Salting-Out Phenomena. J. Phys. Chem. B 114, 2004-2014 (2010)

24. Chen, X., Yang, T., Kataoka, S., Cremer, P.S.: Specific Ion Effects on Interfacial Water Structure near Macromolecules. J. Am. Chem. Soc. 129, 12272-12279 (2007)

25. O'Brien, J.T., Prell, J.S., Bush, M.F., Williams, E.R.: Sulfate Ion Patterns Water at Long Distance. J. Am. Chem. Soc. 132, 8248-8249 (2010)

26. Omta, A.W., Kropman, M.F., Woutersen, S., Bakker, H.J.: Negligible Effect of Ions on the Hydrogen-Bond Structure in Liquid Water. Science 301, 347-349 (2003)

27. Prell, J.S., O'Brien, J.T., Williams, E.R.: Structural and Electric Field Effects of Ions in Aqueous Nanodrops. J. Am. Chem. Soc. 133, 48104818 (2011)

28. Pan, J.X., Xu, K., Yang, X.D., Choy, W.Y., Konermann, L.: SolutionPhase Chelators for Suppressing Nonspecific Protein-Metal Interactions in Electrospray Mass Spectrometry. Anal. Chem. 81, 5008-5015 (2009)

29. Flick, T.G., Merenbloom, S.I., Williams, E.R.: A Simple and Robust Method for Determining the Number of Basic Sites in Peptides and Proteins Using Electrospray Ionization Mass Spectrometry. Anal. Chem. 83, 2210-2214 (2011)

30. Chowdhury, S.K., Katta, V., Beavis, R.C., Chait, B.T.: Origin and Removal of Adducts (Molecular Mass=98 U) Attached to Peptide and Protein Ions in Electrospray Ionization Mass-Spectra. J. Am. Soc. Mass Spectrom. 1, 382-388 (1990)

31. Pan, P., Gunawardena, H.P., Xia, Y., McLuckey, S.A.: Nanoelectrospray Ionization of Protein Mixtures: Solution pH and Protein pI. Anal. Chem. 76, 1165-1174 (2004)

32. Liu, C.L., Wu, Q.Y., Harms, A.C., Smith, R.D.: On Line Microdialysis Sample Cleanup for Electrospray Ionization Mass-Spectrometry of Nucleic Acid Samples. Anal. Chem. 68, 3295-3299 (1996)

33. Pan, P., McLuckey, S.A.: The Effect of Small Cations on the Positive Electrospray Responses of Proteins at Low pH. Anal. Chem. 75, 54685474 (2003) 
34. Iavarone, A.T., Udekwu, O.A., Williams, E.R.: Buffer Loading for Counteracting Metal Salt-Induced Signal Suppression in Electrospray Ionization. Anal. Chem. 76, 3944-3950 (2004)

35. Sterling, H.J., Batchelor, J.D., Wemmer, D.E., Williams, E.R.: Effects of Buffer Loading for Electrospray Ionization Mass Spectrometry of a Noncovalent Protein Complex That Requires High Concentrations of Essential Salts. J. Am. Soc. Mass Spectrom. 21, 1045-1049 (2010)

36. Bauer, K.H., Knepper, T.P., Maes, A., Schatz, V., Voihsel, M.: Analysis of Polar Organic Micropollutants in Water with Ion Chromatography Electrospray Mass Spectrometry. J. Chromatogr. A 837, 117 128 (1999)

37. Dalluge, J.J.: Mass Spectrometry for Direct Determination of Proteins in Cells: Applications in Biotechnology and Microbiology. Fresenius $J$. Anal. Chem. 366, 701-711 (2000)

38. Friess, S.D., Daniel, J.M., Hartmann, R., Zenobi, R.: Mass Spectrometric Noncovalent Probing of Amino Acids in Peptides and Proteins. Int. J. Mass Spectrom. 219, 269-281 (2002)

39. Friess, S.D., Zenobi, R.: Protein Structure Information from Mass Spectrometry? Selective Titration of Arginine Residues by Sulfonates. J. Am. Soc. Mass Spectrom. 12, 810-818 (2001)

40. Salih, B., Zenobi, R.: Maldi Mass Spectrometry of Dye-Peptide and Dye-Protein Complexes. Anal. Chem. 70, 1536-1543 (1998)

41. Wang, G.D., Cole, R.B.: Effect of Solution Ionic-Strength on Analyte Charge-State Distributions in Positive and Negative-Ion
Electrospray Mass-Spectrometry. Anal. Chem. 66, 3702-3708 (1994)

42. Turner, K.B., Monti, S.A., Fabris, D.: Like Polarity Ion/Ion Reactions Enable the Investigation of Specific Metal Interactions in Nucleic Acids and Their Noncovalent Assemblies. J. Am. Chem. Soc. 130, 1335313363 (2008)

43. Jiang, Y.J., Cole, R.B.: Oligosaccharide Analysis Using Anion Attachment in Negative Mode Electrospray Mass Spectrometry. J. Am. Soc. Mass Spectrom. 16, 60-70 (2005)

44. Cai, Y., Cole, R.B.: Stabilization of Anionic Adducts in Negative Ion Electrospray Mass Spectrometry. Anal. Chem. 74, 985-991 (2002)

45. Stephenson, J.L., McLuckey, S.A.: Gaseous Protein Cations are Amphoteric. J. Am. Chem. Soc. 119, 1688-1696 (1997)

46. Stephenson, J.L., McLuckey, S.A.: Counting Basic Sites in Oligopeptides Via Gas-Phase Ion Chemistry. Anal. Chem. 69, 281-285 (1997)

47. Leblanc, J.C.Y., Beuchemin, D., Siu, K.W.M., Guevremont, R., Berman, S.S.: Thermal-Denaturation of Some Proteins and Its Effect on Their Electrospray Mass-Spectra. Org. Mass Spectrom. 26, 831-839 (1991)

48. Gatlin, C.L., Tureček, F.: Acidity Determination in Droplets Formed by Electrospraying Methanol-Water Solutions. Anal. Chem. 66, 712-718 (1994)

49. Simons, J., Kosters, H.A., Visschers, R.W., de Jongh, H.H.J.: Role of Calcium as Trigger in Thermal $\beta$-Lactoglobulin Aggregation. Arch. Biochem. Biophys. 406, 143-152 (2002) 